\title{
Implementation of earthquake mitigation at the engineering faculty, university of mataram
}

\author{
Teti Zubaidah ${ }^{1,2^{*}}$, Rosmaliati ${ }^{1,2}$, Cipta Ramadhani $^{1,2}$, and Dwi Ratnasari ${ }^{1,2}$ \\ ${ }^{1}$ Center of Excellence in Science and Technology on Geomagnetic, University of Mataram, Indonesia \\ ${ }^{2}$ Electrical Engineering Department, University of Mataram, Indonesia
}

\begin{abstract}
After the 2018 Lombok earthquakes, buildings within the Engineering Faculty of the University of Mataram (FT Unram), were severely damaged and there have been no comprehensive treatments. Facilities to support earthquake mitigation, such as signs for evacuation routes and assembly points (temporary evacuation sites), are still minimal, and even if they are available many of them are not designed and placed properly. Some parts of the buildings have been partially renovated, meanwhile, there are new buildings constructions that have not been investigated related to disaster mitigation. Anticipating the re-occurrence of big earthquakes in Lombok, it is very necessary to carry out activities for implementing earthquake mitigation at FT Unram. The activities are divided into three stages, namely first: conducting direct reviews for inventory and documentation of all vulnerable points, followed by making of maps and building plans; second: determining the proper locations of assembly points, creating labels and signs for evacuation routes and assembly points, and making tutorial videos on safety instructions; third: socialization to the policymakers (Faculties and Department's officials), and outreach as well as evacuation drill for all academic communities. The expected output of these activities is increasing of understanding and skills of the academic community in conducting disaster mitigation at their workplaces and application of technology as well as recommendations for disaster risk reduction policies at the faculty and university level.
\end{abstract}

\section{Introduction}

Lombok earthquakes were occurred with the mainshock on $5^{\text {th }}$ August 2018, with M 6.9 as reported by USGS [1] and GEOFON [2], and $\mathrm{M} 6.8$ by BMKG as a representation of national authority [3]. Fig. 1 shows the shake map generated with Did You Feel It (DYFI) as a product report of USGS [4]. According to the map, ground shaking reached MMI VIII to IX in the vicinity of the epicenter, which corresponds to severe to violent shakings and moderate to heavy damages. While in Mataram city (the distance around $80 \mathrm{~km}$ from epicenter) ground shakings reached MMI VI to VII, which correspond to strong to very strong shakings and light to moderate damages. However, at the University of Mataram heavy damages were also found and causing several buildings to collapse. At the Engineering Faculty of the University of Mataram (FT Unram), light to heavy damages was found, without collapse of any buildings.

Three years after the 2018 Lombok earthquakes, damaged buildings within FT Unram have not been treated comprehensively. Indeed a few months after the quakes, facilities to support earthquake mitigations, such as signs for evacuation routes and assembly (temporary evacuation) points, have been created. However, the available signs are still minimal, and many of them are not designed and placed properly. Some parts of the damaged buildings have been partially renovated, meanwhile, some new building constructions have not been studied related to disaster mitigations.

Anticipating the re-occurrence of big earthquakes in Lombok, it is very necessary to carry out activities for implementing earthquake mitigation at FT Unram. Careful investigations have been started in 2020 and reinvestigations are conducted in 2021 in considering some partial renovations and additional buildings.

\section{Methods}

The methods are divided into 3 (three) stages which are expected to be completed over three years from 20212023, with the following stages:

Stage \#1 (2021): Conducting a direct review for inventory and documentation of all vulnerable points, followed by making maps/buildings.

Stage \#2 (2022): Determining the proper locations of assembly points (temporary evacuation sites), creating

\footnotetext{
${ }^{*}$ Corresponding Author: tetizubaidah@unram.ac.id
} 
labels and signs for evacuation routes and assembly points, and making tutorial videos on safety instructions.

Stage \#3 (2023): Socialization to the policymakers (Faculties and Department's officials), and outreach as well as evacuation drill for all academic communities.

Because of pandemic situations, socialization for policymakers and outreach for all communities is considered possible to be conducted only in the third year.

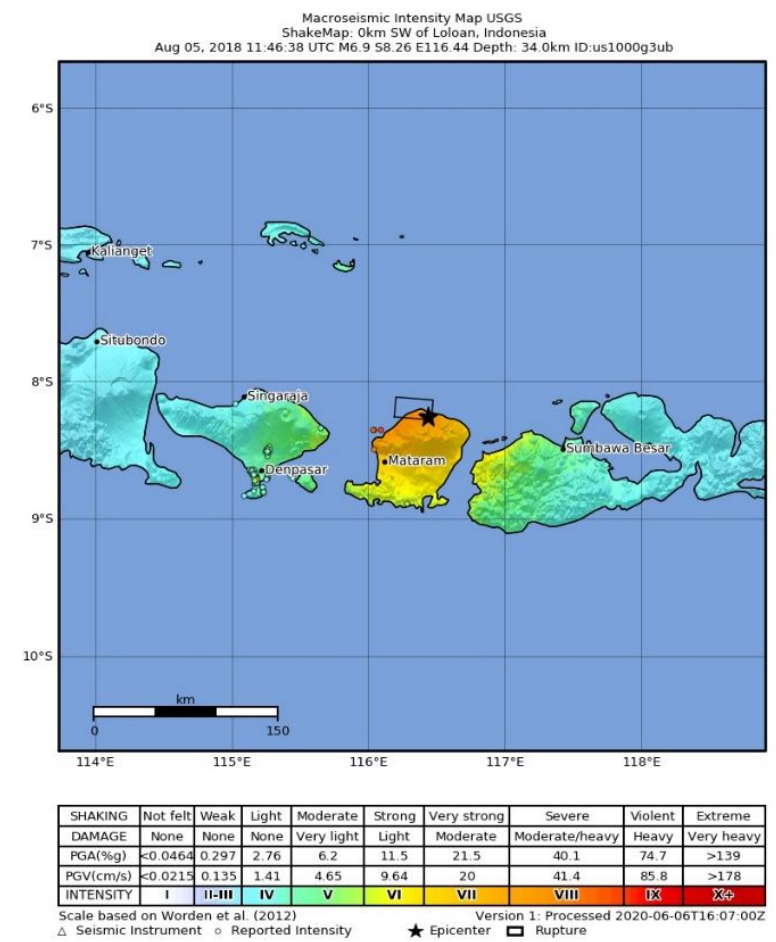

Fig. 1. Shakemap of the Lombok mainshock earthquake on $5^{\text {th }}$ August 2018, generated with DYFI USGS [4].

\subsection{Site Plan}

The site plan of FT Unram is depicted in Fig. 2, with the positions of investigated buildings are marked as A, B, $\mathrm{C} 1, \mathrm{C} 2, \mathrm{C} 3$, and D. In all parts of these buildings careful investigations of actual conditions have been carried out to find out all points of vulnerability, that need to be anticipated for earthquake mitigations.

\subsection{Investigations on Buildings}

Investigations on all buildings have been carried out and continued. Here are descriptions of ongoing investigations up to $30^{\text {th }}$ September 2021.

\subsubsection{Building A}

This building is the administrative center where the Dean and Vice Deans and faculty staffs have their offices on the $1^{\text {st }}$ floor. There is a library and the Informatics Engineering study program on the $2^{\text {nd }}$ floor, while a common meeting room is placed on the $3^{\text {rd }}$ floor.

Fig. 3 shows the atmosphere on the $1^{\text {st }}$ floor, where a corridor is narrow and blocked with several piles of goods because there is a warehouse at the end of the corridor. In Fig. 4 some staff occupied a narrow place under the stair, due to the lack of available spaces, while the condition of the walls in that room was quite dangerous. Fig. 5 shows the library with several reading shelves (some of them are made of glasses) are placed very closely together. Fig. 6 shows some cracks in the outside walls of the $3^{\text {rd }}$ floor of the building. Since current renovations are only inside the building, these cracks will not be treated, because they can only be observed by seeing carefully through a window in the corner of the $3^{\text {rd }}$ floor.

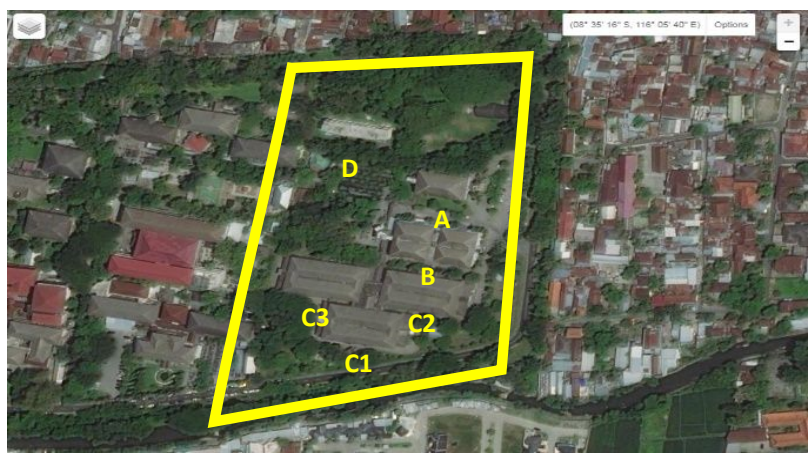

Fig. 2. Site plan of FT Unram with the investigated buildings (A, B, C1, C2, C3, and D), created with earth explorer [5].

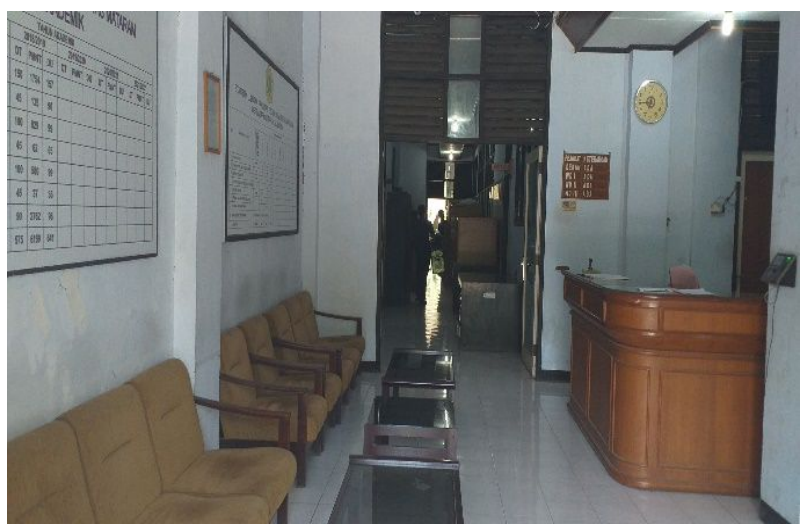

Fig. 3. Daily situations of the $1^{\text {st }}$ floor of Building A.

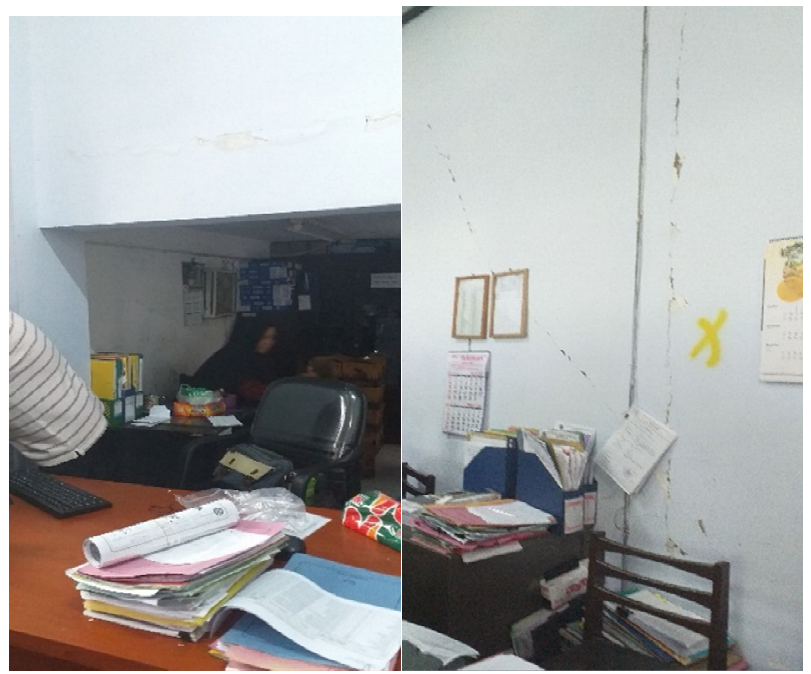

Fig. 4. Staff is working on a narrow place under stairs, and conditions of walls on the $1^{\text {st }}$ floor of Building A. 


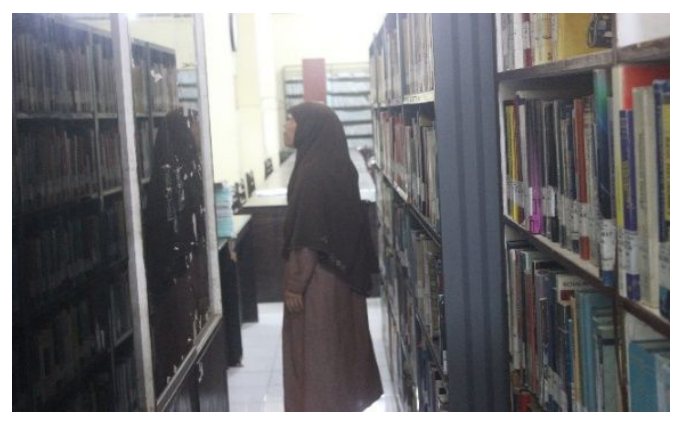

Fig. 5. The library with several reading shelves (some of them are made of glasses) is placed very closely together on the $2^{\text {nd }}$ floor of Building A.

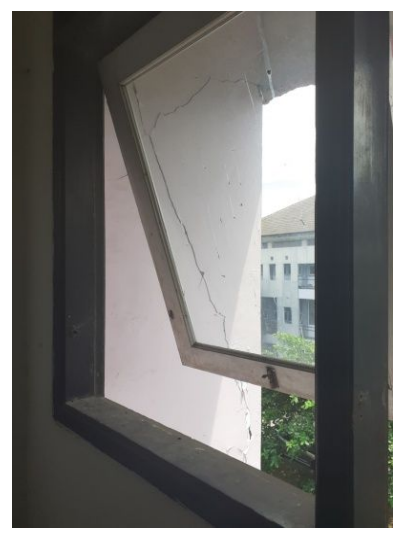

Fig. 6. Cracks in the outside walls of the $3^{\text {rd }}$ floor of Building A.

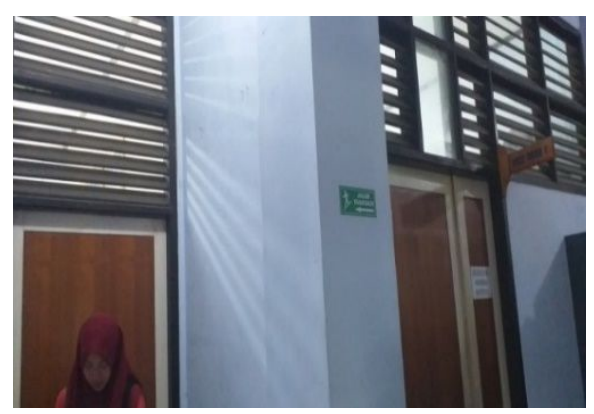

Fig. 7. For an example of a misplaced and misused evacuation symbol on Building A, here a ladder symbol was used on a straight path.

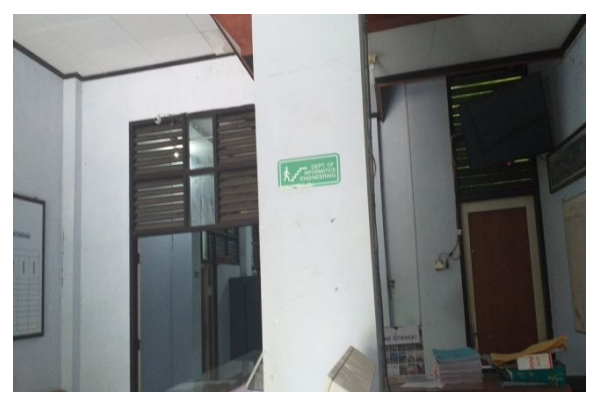

Fig. 8. Example of a misused symbol on Building A, here the same symbol as evacuation one was used to give information of direction to a study program, which on a panic situation it might be misinterpreted as an evacuation route.

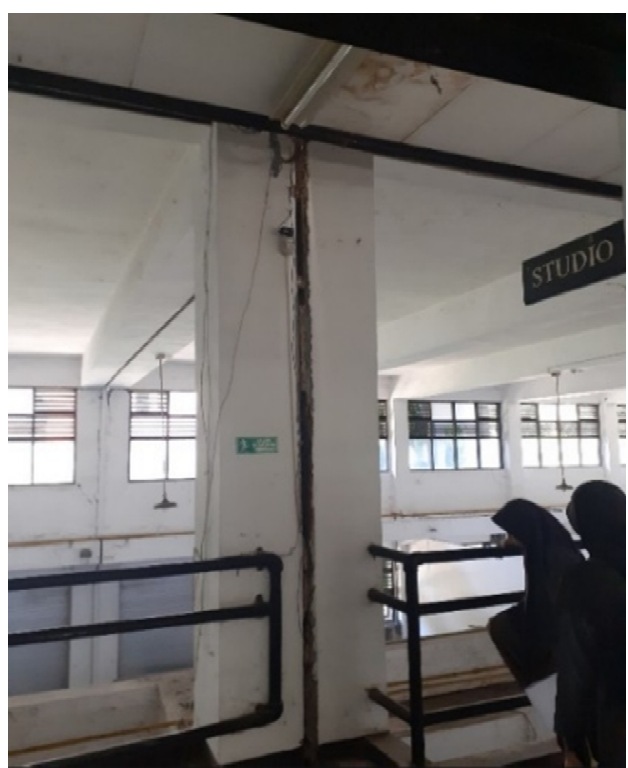

Fig. 9. A large crack between two columns was observed from the $2^{\text {nd }}$ floor of Building B; the crack is initially from the ground floor.

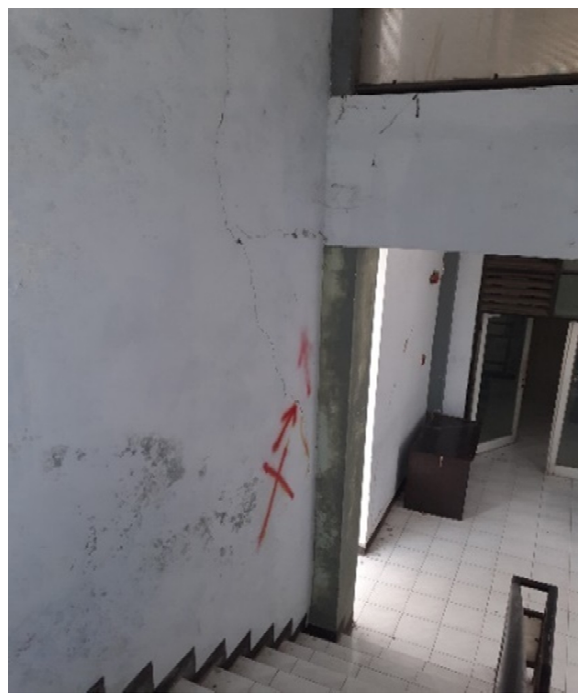

Fig. 10. A large crack in the wall beside the hanging stair, connecting the $2^{\text {nd }}$ and the $3^{\text {rd }}$ floor of Building B.

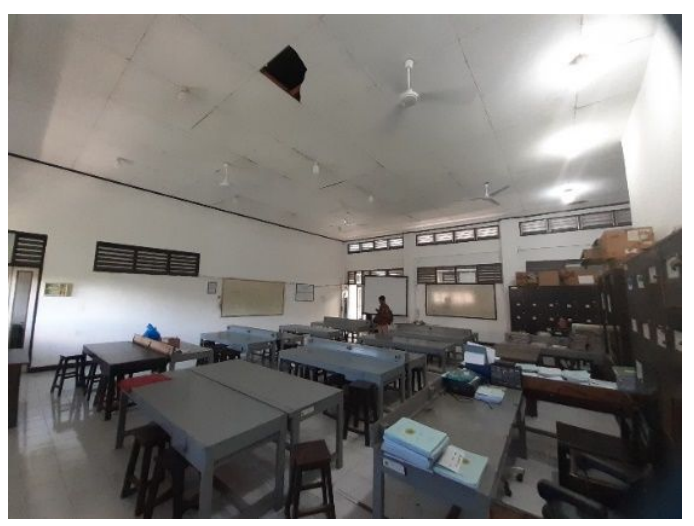

Fig. 11. A large crack on the ceiling of the electrical laboratory on the $3^{\text {rd }}$ floor of Building B. 


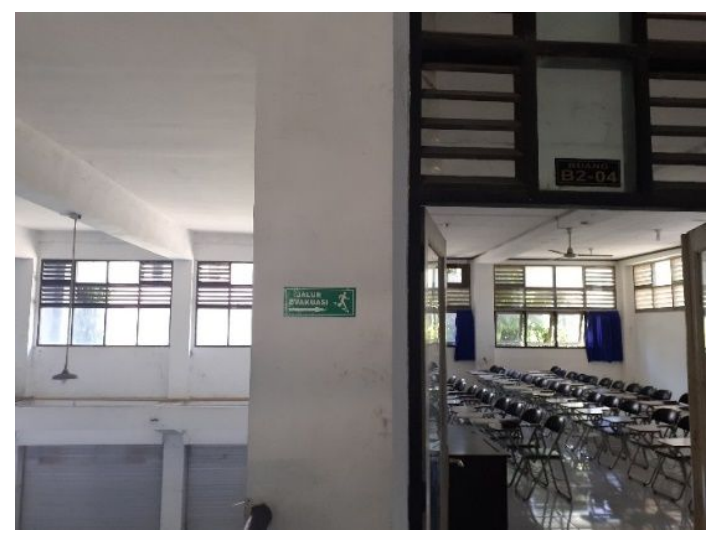

Fig. 12. Example of a misplaced evacuation symbol on Building B, which is quite impossible to be seen by the people who come out from the classroom.

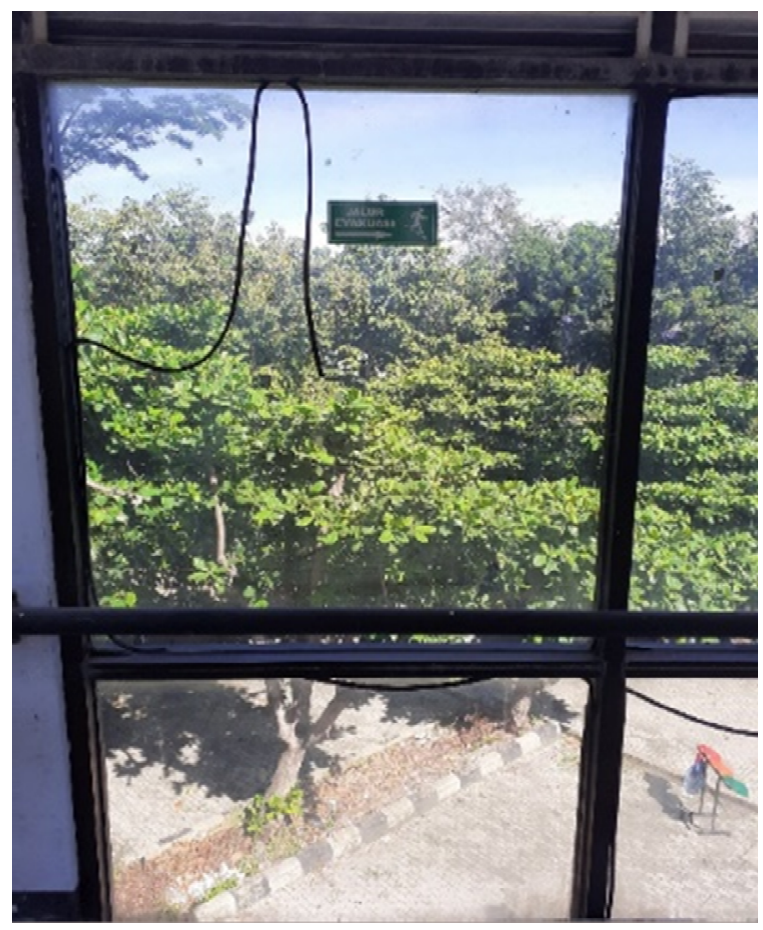

Fig. 13. An example of a misplaced evacuation symbol on Building B, placed on a glass window which is most probably broken firstly on a large earthquake.

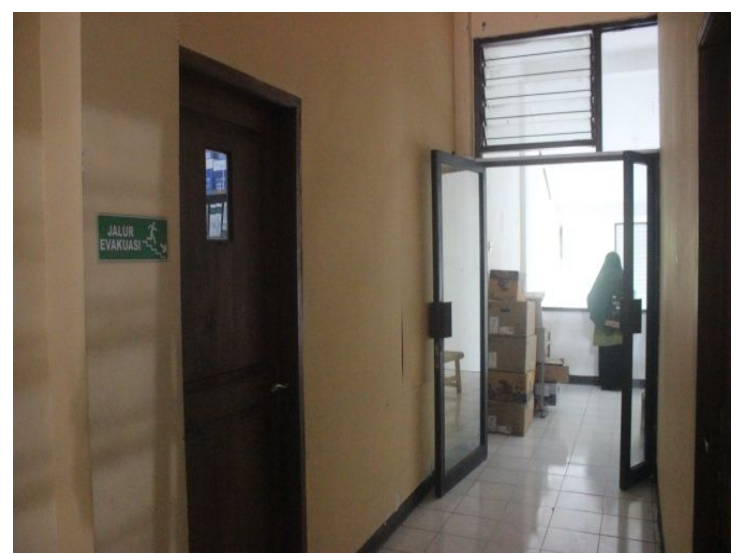

Fig. 14. A misplaced evacuation symbol on Building $\mathrm{C} 1$ might be misunderstood there is a staircase behind the door.

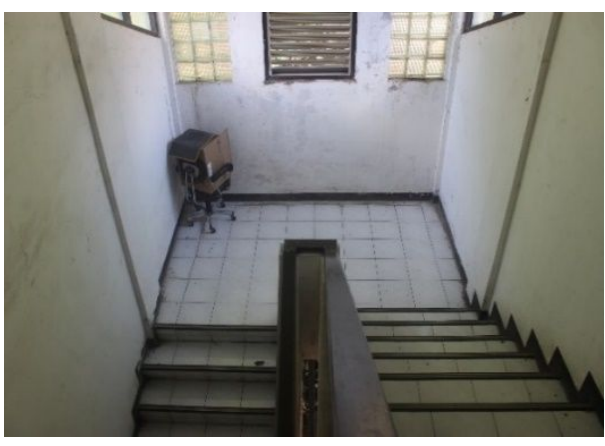

Fig. 15. Inaccessible evacuation route in Building $\mathrm{C} 1$, some items are placed in the stair and the next door is locked.

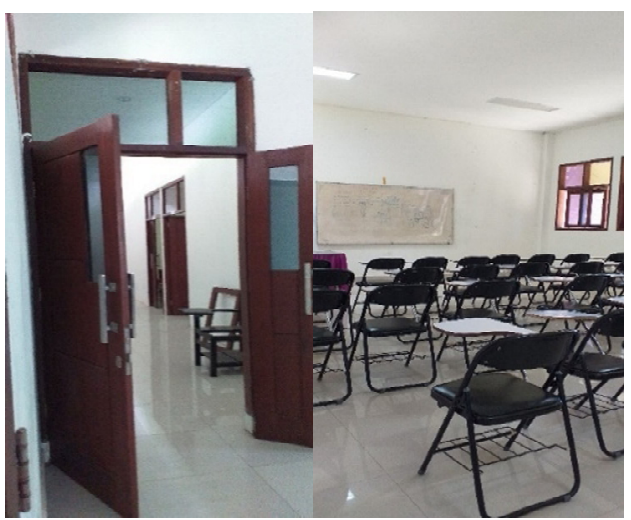

Fig. 16. Site plan of FT Unram with Buildings under investigation (A, B, C1, C2, C3, and D).

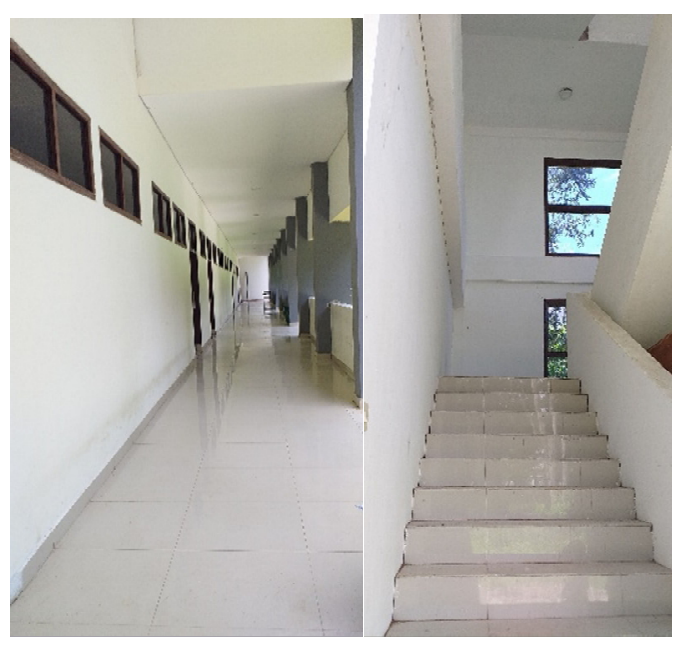

Fig. 17. Site plan of FT Unram with Buildings under investigation (A, B, C1, C2, C3, and D).

In this building, there were evacuation signs, but often installations and the symbols used are not correct. Fig. 7 is an example of an evacuation sign with a ladder symbol was placed, even though what is meant is only going straight. Fig. 8 shows a symbol that commonly resembles an evacuation sign, even though what is meant is showing the direction to reach the Informatic Engineering study program. In a panic situation, this sign might be misinterpreted. The placements of these evacuation signs are higher than the standard, which should be between 120 $-160 \mathrm{~cm}$ above the level [6]. 


\subsubsection{Building $B$}

This building is the administration room, lecture rooms, and laboratories of Mechanical Engineering and Electrical Engineering study programs. There are quite a large number of damages on this building, including heavy damage on the $1^{\text {st }}, 2^{\text {nd }}$, and $3^{\text {rd }}$ floors. Fig. 9 shows a large crack that can be observed on the $2^{\text {nd }}$ floor. It is a connection between two columns, that are heavily fractured already from the ground floor. Some of the walls including one beside the hanging stair Fig. 10 had large cracks, and the ceiling of the laboratory on the $3^{\text {rd }}$ floor was also broken in Fig. 11.

Many evacuation symbols are installed incorrectly, for example, it placed on the wall in the direction of the classroom door in Fig. 12, which is quite impossible for the people who come out of the room to see the sign. Several symbols are placed on the glass windows or glass doors in Fig. 13, which will most probably be broken firstly on a large earthquake.

\subsubsection{Building C}

Compared to the other two previous buildings, damage to this building was quite minimal, especially in Building $\mathrm{C} 1$. While in Buildings $\mathrm{C} 2$ dan $\mathrm{C} 3$ there were some minor damages on the $2^{\text {nd }}$ floor; but the exact number of vulnerabilities could not be identified yet. The evacuation symbols are also in good availability in all important places. However, there was a misplaced symbol as depicted in Fig. 14. The symbol with ladder sign placed next to a closed glass door, which might be misunderstood that there is a staircase behind the door by guests; even though what is meant is an evacuation route and the stair is in the next position route (just after a large glass door). If we try to follow the route through the stair, it was inaccessible because the next door was locked and there were some items placed in the middle of the stairs, as depicted in Fig. 15.

\subsubsection{Building $D$}

In this building damages are not so visible, because the finished construction before the 2018 Lombok earthquakes was only for the $1^{\text {st }}$ floor; and the rest three floors were only completed in the middle year of 2021. However, the condition of the corridors and stairs is very narrow (Fig. 17), which raises difficulties for people to evacuate. The wooden doors of some classrooms (Fig. 18) are difficult to open, which might cause some other vulnerabilities. Careful inspections on this building construction during the last few months show that there seems to be a slight slope in the concrete columns starting from the $2^{\text {nd }}$ floor. Because of this, we must continue more detailed investigations.

\subsection{Evacuation Plans}

Further mapping is carried out to obtain the most probable position for the location of the assembly points and temporary evacuation points. The map was generated by using Google Earth Pro [7], which can be used also to identify the length of the curve and the areas of each shape.

\section{On-Going Results}

\subsection{Identification and Mapping of Vulnerable Points}

Fig. 18 is an example of a building sketch that shows all vulnerable points and levels of vulnerability in detail. This drawing is equipped with point codes and an accompanying document that describe the vulnerability of each point, also documentation in the form of photos and videos of each vulnerable point.

Results of calculation of the number of vulnerable points and their categories for each building and each floor as shown in Table 1. It appears that Buildings A and $\mathrm{B}$ are the most vulnerable and need immediate attention, while Building $\mathrm{C}$ is relatively safer. Meanwhile, in Building D, we have not finished collecting data and must continue more detailed investigations.

\subsection{Proposal for Evacuation Plans}

Assembly points and evacuation routes are proposed based on the Evacuation Plans in Fig. 19. The buildings and surrounding closest areas are considered not to be used for assembly points [8]; they are marked as areas with white colors. Permanent obstacles including a wind power turbine, a large power transformator, and semipermanent buildings are considered not possible for assembly points; they are marked as areas with red colors. Temporary obstacles including parking areas are also considered not suitable for assembly points; they are marked as areas with blue colors.

The results of the calculation are depicted in Table 2, where we get free spaces of about $15,000 \mathrm{~m}^{2}$. If it is assumed that only $10 \%$ of them can be used as assembly points, then the available spaces are about $1,500 \mathrm{~m}^{2}$. Considering the capacity of 1000 people (according to the number of students, lecturers, staff, and guests), we will get approximately $1.5 \mathrm{~m}^{2}$ area per person, which is still suitable for social distancing conditions (if an earthquake occurs while we are still in pandemic conditions). In a normal condition where people only need free space of about $0.3 \mathrm{~m}^{2}$ according to standard [8], the available spaces are quite enough.

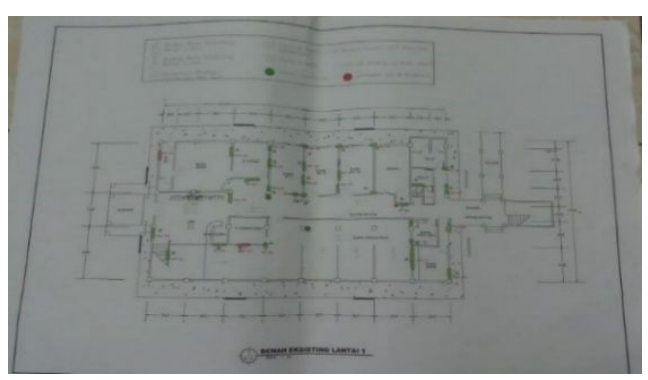

Fig. 18. Sketch of Building A, showing all vulnerable points. 
Table 1. Vulnerable points and their categories for Buildings at Engineering Faculty of the University of Mataram.

\begin{tabular}{|c|c|c|c|c|c|}
\hline $\begin{array}{c}\text { Build- } \\
\text { ing }\end{array}$ & $\begin{array}{c}\text { Flo- } \\
\text { or }\end{array}$ & Light & $\begin{array}{c}\text { Medi- } \\
\text { um }\end{array}$ & Heavy & Total \\
\hline \multirow{4}{*}{ A } & 1 & 20 & 17 & 2 & 29 \\
\cline { 2 - 6 } & 2 & 5 & 9 & 1 & 15 \\
\cline { 2 - 6 } & 3 & 4 & 11 & 4 & 19 \\
\hline \multirow{3}{*}{ B } & 1 & 18 & 17 & 5 & 40 \\
\cline { 2 - 6 } & 2 & 30 & 10 & 4 & 44 \\
\cline { 2 - 6 } & 3 & 0 & 5 & 0 & 5 \\
\hline \multirow{3}{*}{ C1 } & 1 & 1 & 0 & 0 & 1 \\
\cline { 2 - 6 } & 2 & 0 & 0 & 0 & 0 \\
\hline \multirow{2}{*}{ C2 } & 1 & 0 & 0 & 0 & 0 \\
\cline { 2 - 6 } & 2 & NA & NA & NA & NA \\
\hline \multirow{2}{*}{ C3 } & 1 & 0 & 0 & 0 & 0 \\
\cline { 2 - 6 } & 2 & NA & NA & NA & NA \\
\hline \multirow{3}{*}{ D } & 1 & NA & NA & NA & NA \\
\cline { 2 - 6 } & 2 & NA & NA & NA & NA \\
\cline { 2 - 6 } & 3 & NA & NA & NA & NA \\
\cline { 2 - 6 } & 4 & NA & NA & NA & NA \\
\hline
\end{tabular}

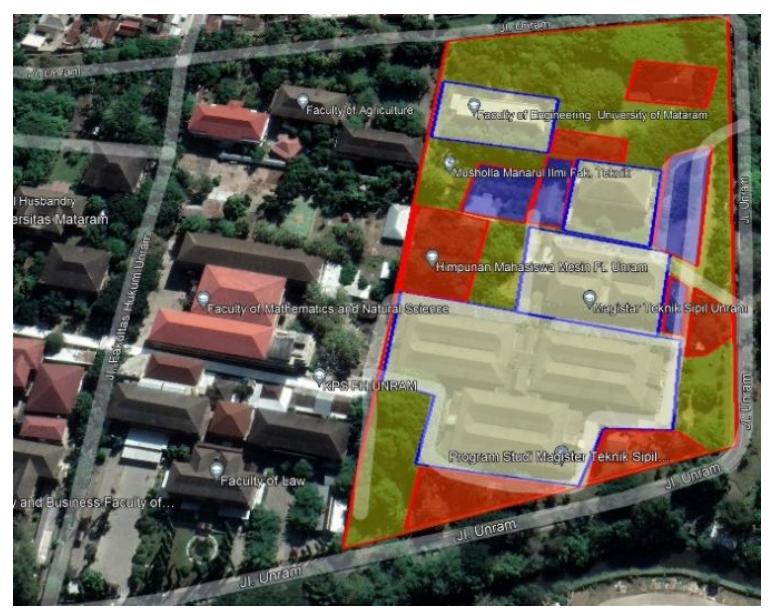

Fig. 19. Evacuation plans of FT Unram, showing all available free space areas (green) which can be used as assembly points, while buildings (white) and permanent- (red) and temporary(blue) obstacles are considered not suitable for assembly points. The map was generated by using Google Earth Pro [7].

Table 2. Proposal for assembly/temporary evacuation points at Engineering Faculty of the University of Mataram.

\begin{tabular}{|c|c|}
\hline Considered Space & Area $\mathbf{( m}^{\mathbf{2}} \mathbf{}$ \\
\hline Total area & 39,575 \\
\hline Buildings & 15,481 \\
\hline Permanent Obstacles & 5,116 \\
\hline Temporary Obstacles & 3,019 \\
\hline Free spaces & 15,959 \\
\hline $10 \%$ availability & 1,595 \\
\hline Capacity for 1,000 persons & 1.5 \\
\hline
\end{tabular}

\section{Outputs and Final Results}

The targeted outputs of activities are increasing of understanding and skills of the academic community in conducting disaster mitigation at their workplaces and application of technology as well as recommendations for disaster risk reduction policies at the faculty and university level. The results of these activities are:

1) Availability of documents and maps of vulnerability points,

2) Availability of earthquake mitigation facilities,

3) Implementation of research products, in the form of studies on vulnerability and risk levels due to earthquakes,

4) Increasing awareness and skills of the FT Unram academic community in mitigating earthquakes, so that will significantly reduce the level of vulnerability and risks,

5) Availability of policy recommendation documents to increase resilience to earthquake re-occurrences in the future.

\section{Conclusions}

Activities for implementation of earthquake mitigation have been conducted at FT Unram, and at this stage resulted in documents and maps of vulnerability points and proposals for assembly points. Considering the number of vulnerable points, Building B is considered the most vulnerable, while building $\mathrm{C}$ is the safest one. The available area of proposed assembly points is wide enough for 1000 people and suitable for social distancing (if an earthquake occurs during pandemic conditions).

These activities and related publications are funded by PNBP DIPA BLU UNRAM under contract number 1895/UN18.L1/PP/2021 entitled "Implementasi Mitigasi Gempa Bumi di Fakultas Teknik Universitas Mataram". We thank to students who actively involved in these activities (Alif Adi Prasetya, I Made Wisnu Kusuma Putra, Ramdani Saputra, Muhammad Abulloh Hamzan, Irma Yunihad, Krisdian Ambarwati, Fitrianti Rukmana, Sekar Sari Bintang Solehah, and Khairunnisak).

\section{References}

1. USGS, https://earthquake.usgs.gov/earthquakes/ eventpage/us1000g3ub/executive, accessed on 07 October 2021

2. GEOFON, http://geofon.gfz-potsdam.de/eqinfo/ event.php?id=gfz2018pfnz, accessed on 07 October 2021

3. BMKG, http://repogempa.bmkg.go.id/repo_new/, accessed on 07 October 2021

4. USGS, https://earthquake.usgs.gov/earthquakes/ eventpage/us1000g3ub/shakemap/intensity, accessed on 07 October 2021

5. USGS, https://earthexplorer.usgs.gov/, accessed 07 October 2021

6. Curtin University, PDG Emergency Management Design Guidelines 000331, 
https://properties.curtin.edu.au/local/docs/guidelines /000331-Emergency-Management-DesignGuidelines-2020-02.pdf, accessed on 07 October 2021 (2020)
7. Google Earth Pro, https://www.google.com/earth/ versions/\#earth-pro, accessed on 07 October 2021 16:01 WITA

8. PUPR, Permen PUPR No. 14 tentang Persyaratan Kemudahan Bangunan Gedung (2017) 